УДК 378.18

Ю. М. Жилясва,

кандидат педагогічних наук, старший викладач

(Житомирський державний університет імені Івана Франка) yulia_zhyl@yahoo.com

ORCID: $0000-0003-4841-9233$

\title{
РОЛЬ ТА МІСЦЕ КУРСУ АНГЛІЙСЬКОЇ МОВИ В ПРОЦЕСІ ПРОФЕСІОНАЛІЗАЦІЇ СТУДЕНТІВ-ПОЛІТОЛОГІВ
}

У статті досліджуються організаційні та методичні засади забезпечення професіоналізації студентів у вищому навчальному закладі шляхом посилення співпраці між викладачами фахових дисциплін та курсу іноземної мови. Запропоновано засоби та форми роботи в рамках іншомовної підготовки студентів $з$ метою створення моделі професійного середовища, професійної діяльності та Я-концепцї майбутніх політологів, які становлять психологічну модель професії. Визначено алгоритм розробки навчального модуля з іноземної мови, орієнтованого на професіоналізацію студентів.

Ключові слова: професіоналізація студентів, первинна професіоналізація політологів, міждисциплінарні зв'язки, навчальний модуль з іноземної мови, іноземна мова професійного вжитку.

Постановка проблеми в загальному вигляді. Політичний дискурс в межах однієї країни або мови не може бути достатнім джерелом інформації для професійного становлення фахівця 3 політології, оскільки таке обмеження призведе до вузького та упередженого розуміння глобальних процесів. Необхідність вивчення першоджерел та ознайомлення з професійним доробком колег, дослідження громадської думки поза межами України вимагає підвищення ролі практичного опанування професійною діяльністю та посилення міжпредметних зв'язків між фаховими дисциплінами та курсом англійської мови в процесі професійної підготовки майбутніх політологів.

Аналіз основних досліджень та публікацій. Сучасні дослідження в сфері іншомовної підготовки здебільшого зосереджені на оптимізації курсу іноземної мови професійного вжитку і розглядають методичні аспекти роботи із студентами. До того ж, недостатньо вивченим залишається питання особливостей іншомовної підготовки політологів з урахуванням їхніх майбутніх професійних потреб. Серед основних напрямів досліджень в цьому напрямі $є$ роботи Дробишевої Н. Н., яка відзначає поліпредметність змісту курсу іноземної мови професійного вжитку як фактор професіоналізації студентів-політологів; Петько Л. В., яка досліджує форми та методи іншомовної підготовки майбутніх політологів; Суткевич Г. О. та Москалюк О. В., які вивчають методику навчання студентів-політологів конкретних видів комунікативної діяльності, зокрема, діалогу, аргументації, публічного мовлення тощо. В контексті нашого дослідження велике значення має доробок Рябенко Н. Л., яка розглядає контекстне навчання при підготовці політологів. Незважаючи на потужний потенціал цього підходу, дослідження в цьому напрямі носять вузький характер та не виходять поза межі методики викладання іноземних мов, що призводить до ототожнення результатів наукових розвідок в сфері контекстного навчання 3 результатами дослідження інтерактивних методів навчання при вивченні іноземних мов (зокрема, рольових, імітаційних, ділових ігор тощо).

Професіоналізація студентів у рамках курсу іноземної мови потребує більш системного підходу та моделювання професійної діяльності майбутніх політологів, що вимагає посилення співробітництва між викладачами фахових дисциплін та англійської мови і дослідження ефективності їх взаємодії. Отже, засади контекстного навчання з метою реалізації професіоналізації студентів-політологів за допомогою курсу англійської мови є перспективним напрямом дослідження з метою оптимізації іншомовної та фахової підготовки майбутніх спеціалістів.

Метою цієї статті $€$ визначення форм та методів навчально-виховної роботи 3 метою професіоналізації студентів-політологів засобами іноземної мови. Розвідка передбачає виконання таких завдань: визначити поняття професіоналізації та іiі структуру; окреслити форми та методи реалізації компонентів процесу професіоналізації студентів; запропонувати форми та методи аудиторної та позааудиторної роботи студентів-політологів над застосуванням іноземної мови 3 метою професіоналізації.

Виклад основного матеріалу. Професіоналізація є процесом та результатом опанування конкретних видів професійної діяльності та набуття відповідних професійних рис та якостей, тобто становлення професіоналізму [1: 301]. Дружилов С. О. до змісту цього процесу включає набуття знань, умінь, навичок, професійне самоусвідомлення, формування та розвиток цінностей та мотивації до професійної діяльності. Дослідник слушно вводить поняття "модель професії" та "модель професійної діяльності", оскільки в процесі навчальної діяльності студенти можуть лише імітувати професійну діяльність політологів. Водночас поняття "модель" передбачає набуття ними комплексного розуміння професійної діяльності, яку їм належить виконувати в майбутньому. 
Процес професіоналізації реалізується в два етапи. Первинна професіоналізація безпосередньо пов'язана з професійним навчанням, тоді як вторинна професіоналізація відбувається в процесі реалізації професійної діяльності та не має часових меж. У вищому навчальному закладі відбувається первинна професіоналізація студентів, до складових якої дослідники відносять набуття знань, умінь та навичок, необхідних для успішної реалізації професійної діяльності [2: 173], засвоєння культурного досвіду людства, професійну соціалізацію, формування активної життєвої та професійної позиції [3: 71], соціально-професійних рис особистості, переконань, світоглядної позиції, професійних інтересів, професійних установок, мотивів, ставлень, ціннісних орієнтацій.

Педагогічні засади професіоналізації студентів, на нашу думку, доцільно розглядати з точки зору контекстного навчання - теорії, запропонованої Вербицьким А. А., яка полягає в послідовному моделюванні в навчальній діяльності предметного та соціального змісту майбутньої професійної діяльності, з поступовою зміною пізнавальної діяльності на професійну, що не лише вимагає тісного співробітництва між конкретними викладачами фахових дисциплін та спеціалізованими кафедрами, але й залучення викладачів іноземних мов, адже в політичному дискурсі сьогодення неможливо брати участь без належного володіння англійською мовою.

3 метою подальшого визначення напрямів роботи над професіоналізацією студентів засобами англійської мови ми керуватимемося психологічною моделлю професії, запропонованою Дружиловим С. О., яка складається з трьох компонентів:

- модель професійного середовища, до якої належать об’єкт, предмет, засоби праці, професійні завдання, умови праці та соціальне оточення.

- модель професійної діяльності, яка включає різні шляхи взаємодії спеціаліста із професійним середовищем, цілі, результати та шляхи реалізації цієї взаємодії.

- Я-концепція - уявлення студента про себе в контексті професійної діяльності.

- окремо дослідник також розглядає професійні норми, цінності та загальні цілі професійної діяльності, на яких грунтується кожен із вищезазначених компонентів та наявність яких відрізняє дилетанта від професіонала.

До функцій, які може виконувати курс англійської мови для майбутніх політологів, належать, зокрема: інформаційна, організаційна та контрольна. 3 метою формування моделі іншомовного професійного середовища викладач англійської мови має забезпечити студентів професійно значущою інформацією:

бібліотека іншомовних наукових публікацій з актуальних питань політичного дискурсу;

- медіатека, де в зручний для студентів спосіб представлено відео, аудіо матеріали: виступи політичних діячів, політичних оглядачів, фільми та подкасти, зміст та тематику яких допомагають визначати викладачі фахових дисциплін;

перелік відомих політичних оглядачів та аналітиків, доступ до їхніх веб-сторінок, блогів, програм, подкастів тощо, з методичними матеріалами для самостійного опрацювання тощо.

Організаційна функція полягає в забезпеченні участі студентів у міжнародних конференціях 3 політології англійською мовою, допомозі в організації спілкування з іноземними студентами, колегами, викладачами, респондентами (при проведенні опитувань) тощо. Оскільки теоретичний матеріал студенти опановують під час вивчення фахових дисциплін, частина лекцій, семінарів, домашніх завдань, позааудиторної роботи та контролю знань може здійснюватися англійською мовою.

Контрольна функція є допоміжною та полягає в перевірці засвоєння студентами знань та розуміння інформації про об’єкт, предмет, професійні завдання та соціальне оточення політолога, і за бажанням викладачів фахових дисциплін може здійснюватися англійською мовою.

Розглянемо вищезазначені компоненти моделі професійної діяльності з уточненням їх змісту для студентів-політологів на базі професіограми політолога за Романовою С. С.

Домінуючі види діяльності: вивчення політичних явищ в динаміці, виявлення зв'язку між минулим, теперішнім та майбутнім; вивчення залежності політики, політичних процесів від суспільства, економічних відносин, соціальної структури суспільства, ідеології та культури; встановлення значення політичних явищ для суспільства та особистості, оцінювати їх; вивчати взаємозв'язок між політичними явищами та рівнем економічного розвитку, політичною моделлю, між ступенем урбанізації населення та його політичною активністю, між кількістю партій та виборчою системою тощо; вивчення та аналіз вербальної, практичної, усвідомленої та неусвідомленої поведінки окремих людей та груп; вивчення та аналіз діяльності інститутів, на базі яких здійснюється політична діяльність, зокрема, держава, партія, тощо; вивчення та визначення механізмів політичної поведінки, індивідуальних рис, типових механізмів психологічної мотивації; аналіз політичних явищ 3 метою виявлення їх спільних рис та специфіки, виявлення найефективніших форм політичної організації та оптимальних шляхів рішення завдань; прогнози щодо політичного майбутнього держави, партії, політика тощо. 
До сфер застосування професійних знань належать періодичні видання (газети, журнали тощо), телебачення (телевізійні програми, круглі столи), інформаційні агенції, навчальні заклади, науководослідні установи [4: 278].

Досліджуючи завдання іншомовної підготовки майбутніх політологів, ми виділили комунікативні компетенції, набуття яких необхідно забезпечити з огляду на види професійної діяльності. В рамках організаційно-управлінської діяльності необхідно сформувати навички ведення діалогу та переговорів на професійні теми, встановлення контактів. В рамках майбутньої проектної діяльності студенти мають навчитися враховувати соціальні конвенції ділового спілкування та застосовувати їх. Здійснюючи дипломатичну та міжнародно-політичну діяльність, майбутні політологи мають вміти формулювати переконливі аргументи 3 метою захисту своєї позиції, знаходити компромісні рішення. Для інформаційно-аналітичної діяльності необхідно навчити студентів технік реферування та інформаційноаналітичної роботи. Дослідник виділяє головні продуктивні та рецептивні завдання діалогічного та монологічного мовлення, а саме: інформування співрозмовника, пояснення своєї позиції, вміння переконувати співрозмовника, отримання інформації, розуміння позиції співрозмовника, спілкування телефоном (діалог), та інформаційна промова (монолог).

Проте проектування моделі професії з метою організації навчального процесу потребує більш детального визначення функцій політолога, особливостей його професійної діяльності та комунікативних ситуацій іншомовного спілкування. У наших попередніх роботах виділено іншомовні компетенції політологів, формування яких вимагає співробітництва викладачів фахових дисциплін та дисципліни "Англійська мова":

- Написання аналітичних статей;

- Проведення анкетування, соціологічних досліджень;

- Ведення власного інформаційно-аналітичного ресурсу (веб-сторінки, сторінки у соціальних мережах, блога, телепрограми, радіопрограми тощо);

- Написання заявок на отримання фінансування проектів (грантів);

- Публічні виступи;

- Пошук та аналіз англомовної інформації на професійну тематику;

- Написання та презентація наукових статей за результатами досліджень [5: 49].

Розвиток вищезазначених компетенцій становитиме внесок курсу іноземної мови професійного вжитку в процес формування моделі професійної діяльності і потребує розробки окремих навчальних модулів з огляду на специфічний характер та обсяг змісту навчального матеріалу, а також навичок, які $\epsilon$ метою навчання. Планування навчального модуля з дисципліни "Англійська мова професійного вжитку" детально розглянуто в типовій Програмі з англійської мови для професійного спілкування, розробленій у 2005 році та рекомендованій Міністерством освіти і науки України. Розглянемо процес розробки навчального модуля "Анкетування" на базі вищезазначеної Програми [6].

Алгоритм полягає у визначенні навчальних цілей з урахуванням контексту спілкування професійній діяльності політолога, після чого визначаються мовленнєві уміння та професійні ситуації, аналіз яких дозволяє скласти перелік мовленнєвих функцій та зразків для опанування студентами. На підставі цієї інформації обирається зміст модуля та розробляються навчальні матеріали та завдання.

Анкетування в роботі політолога $є$ важливою складовою діяльності, ресурсом для написання аналітичних статей, досліджень, джерелом інформації для дописів у власних ресурсах, для збору та пошуку інформації на професійну тематику тощо. Анкетування може проводитися при безпосередньому спілкуванні або в дистанційному режимі, проте спільною рисою є письмова комунікація та вміння розробляти анкету. Нижче ми наводимо вміння, комунікативні функції та мовленнєві зразки, розроблені нами на підставі аналізу навчальної літератури 3 фахових дисциплін (зокрема, "Соціологія") та англомовних анкет соціологічних досліджень.

Таблиия 1.

Зміст комунікативних умінь анкетування

\begin{tabular}{|c|c|c|}
\hline \\
\hline Мікровміння & Функцї̈ & Мовленнєві зразки \\
\hline $\begin{array}{l}\text { Складання } \\
\text { вступної частини } \\
\text { анкети }\end{array}$ & $\begin{array}{l}\text { Формулювання назви } \\
\text { Привітання } \\
\text { Опис анкети } \\
\text { Правила заповнення } \\
\text { Подяка } \\
\text { Мотивування опитуваного }\end{array}$ & $\begin{array}{l}\text { This survey is authorized / conducted } \\
\text { by... } \\
\text { We are conducting a survey about... } \\
\text { Please answer all items / questions below } \\
\text { Answer items 1-10 in your own } \\
\text { handwriting } \\
\text { The survey should only take } 5 \text { minutes } \\
\text { Your answers will help us... } \\
\text { Put a check opposite ... } \\
\text { Put a check in the box that corresponds to } \\
\text { the correct answer. }\end{array}$ \\
\hline
\end{tabular}




\begin{tabular}{|c|c|c|}
\hline & & $\begin{array}{l}\text { There can be more than one correct } \\
\text { answer } \\
\text { Put a check in the box that applies to you }\end{array}$ \\
\hline $\begin{array}{l}\text { Формулювання } \\
\text { основного блоку } \\
\text { анкети }\end{array}$ & $\begin{array}{l}\text { Формулювання завдань анкети } \\
\text { Формулювання питань } \\
\text { Використання різних видів } \\
\text { питань (закриті, напівзакриті, } \\
\text { відкриті; основні, контрольні, } \\
\text { фільтруючі, пастки; питання про } \\
\text { події, факти, мотиви, думки, } \\
\text { оцінки; прямі, непрямі, } \\
\text { проективні; екзистенцій ні, } \\
\text { дефінітивні, оціночні, аналітичні, } \\
\text { обгрунтовуючі, конструктивні) }\end{array}$ & $\begin{array}{l}\text { Strongly disagree } \\
\text { Moderately disagree } \\
\text { Slightly disagree } \\
\text { Slightly agree } \\
\text { Moderately agree } \\
\text { Strongly agree } \\
\text { Neither agree nor disagree } \\
\text { Never } \\
\text { From time to time } \\
\text { Regularly } \\
\text { Always / Very often } \\
\text { Which of the following best describes... } \\
\text { Please choose between... } \\
\text { If your answer to the previous question } \\
\text { was..., } \\
\text { Please name... } \\
\text { Please state... } \\
\text { Please elaborate briefly on your answer... } \\
\text { If Yes, go to question... }\end{array}$ \\
\hline $\begin{array}{l}\text { Укладання } \\
\text { заключної частини } \\
\text { анкети }\end{array}$ & $\begin{array}{l}\text { Подяка } \\
\text { "паспортичка" } \\
\text { демографічний блок) }\end{array}$ & $\begin{array}{l}\text { Name of respondent: } \\
\text { Address: } \\
\text { Thank you for your time and suggestions } \\
\text { Thank you for sharing your thoughts with } \\
\text { us }\end{array}$ \\
\hline $\begin{array}{l}\text { Використання } \\
\text { різних типів шкал }\end{array}$ & $\begin{array}{l}\text { Дихотомічна шкала } \\
\text { Шкала відповідей } 3 \text { обмеженою } \\
\text { кількістю альтернатив } \\
\text { Семантичний диференціал } \\
\text { Шкала Лайкерта }\end{array}$ & $\begin{array}{l}\text { Yes-No } \\
\text { True-False } \\
\text { Fair-Unfair } \\
\text { Agree-Disagree } \\
\text { Extremely - Very - Moderately - } \\
\text { Slightly - Not at all }\end{array}$ \\
\hline $\begin{array}{l}\text { Складання звіту: } \\
\text { опис гіпотези, } \\
\text { коментарі, } \\
\text { статистичні дані }\end{array}$ & $\begin{array}{l}\text { Обгрунтувати та описати } \\
\text { методику дослідження } \\
\text { Формулювання проблеми } \\
\text { Мета анкетування, тематика та } \\
\text { форма } \\
\text { Спосіб обробки даних } \\
\text { Вибір аудиторії }\end{array}$ & $\begin{array}{l}\text { To evaluate } \\
\text { To establish the level of } \\
\text { The survey was conducted... (when) } \\
\text { The survey included ... randomly } \\
\text { selected adults aged } 18 \text { and older } \\
\text { Sample group }\end{array}$ \\
\hline $\begin{array}{l}\text { Презентація } \\
\text { результатів } \\
\text { дослідження }\end{array}$ & $\begin{array}{l}\text { (детально див. } \quad \text { Презентація, } \\
\text { Типова програма) } \\
\text { Підкреслення } \\
\text { результатів } \\
\text { Пояснення даних } \\
\text { Демонстрація та пояснення } \\
\text { таблиць та графіків, діаграм } \\
\text { Укладання рекомендацій } \\
\end{array}$ & $\begin{array}{l}\text { The survey shows... } \\
\text { Notable shifts in outlook since... } \\
\text { The survey found that... } \\
\text { The research indicates that... } \\
\text { The sample was selected through... }\end{array}$ \\
\hline
\end{tabular}

Після деталізації мовленнєвих вмінь та зразків необхідно сформулювати цілі та завдання модуля.

Цілі модуля "Проведення та аналіз результатів анкетування":

Практична: розвивати професійно орієнтовані комунікативні компетенції, необхідні для проведення анкетування.

Освітня: набуття студентами декларативних та процедурних знань, необхідних для розробки анкети та проведення анкетування.

Пізнавальна: залучати студентів до самостійного формулювання завдань із пошуку нової інформації.

Розвиваюча: сприяти розвитку відповідальності студентів за якість соціологічних досліджень у професійній площині.

Завдання модуля: "Проведення та аналіз результатів анкетування":

Письмо: складати анкети, складати звіти за результатами анкетування. 
Читання: розвивати навички пошукового та вивчаючого читання 3 метою збору даних та аналізу результатів проведених опитувань

Говоріння: розвивати навички монологічного мовлення з метою презентації результатів анкетування, коментування таблиць, графіків та схем.

Теми для вивчення обираються з огляду на поточну програму з фахових дисциплін або з урахуванням професійних інтересів студентів, наприклад:

- The Principles of Democracy;

- $\quad$ Elections;

- $\quad$ Civic Engagement.

3 метою всебічного охоплення професійно значущої інформації необхідно включити до змісту англомовних навчальних матеріалів різноманітні типи ресурсів, а саме:

- тексти на професійну тематику;

- $\quad$ анкети;

- $\quad$ графіки та діаграми;

- $\quad$ аналітичні статті;

- дописи в соціальних мережах та блогах політологів;

- $\quad$ новини тощо.

В рамках модуля студенти ознайомлюються з типами питань, типами шкал, частинами анкети, навчаються формулювати питання для анкетування, презентувати результати власних досліджень на підставі зразків, які добирає викладач.

Досліджуючи проблему формування моделі професії, необхідно окремо зупинитися на розвитку уявлення студентів про себе в контексті професійної діяльності, на формуванні "Я-концепції". 3 точки зору змісту курсу англійської мови професійного вжитку найбільш доцільним ми вважаємо включення блоку самоаналізу та рефлексії до кожної навчальної теми. Так, студентам пропонуються різні види тестів англійською мовою для оцінювання себе, власних знань, умінь, уподобань, цінностей з метою аналізу своїх здібностей та нахилів, вибору напряму подальшої професійної діяльності, формування ставлень до різних явищ та персоналій.

Висновки та перспективи подальших досліджень. На підставі теорії контекстного навчання, а також психологічної моделі професії ми уточнили зміст та цілі професіоналізації майбутніх політологів за допомогою курсу англійської мови у ВН3, а також запропонували організаційно-педагогічні та методичні умови реалізації міжпредметних зв'язків між фаховими дисциплінами та курсом англійської мови з метою забезпечення професіоналізації майбутніх політологів. Подальшого вивчення потребує питання ранньої професіоналізації студентів за допомогою іноземної мови, оскільки курс англійської мови як такий може бути потужним джерелом фахової інформацій, проте англійська мова професійного вжитку викладається лише з третього курсу.

\section{СПИСОК ВИКОРИСТАНИХ ДЖЕРЕЛ ТА ЛІТЕРАТУРИ}

1. Дружилов С. А. Освоение студентами модели профессии и профессиональной деятельности как необходимое условие профессионализации / С. А. Дружилов // Образовательные технологии и общество (Educational Technology \& Society). - 2010. - T. 13. - № 4. - С. 299-318.

2. Иванов В. Г. Профессиональное становление студентов и процесс профессионализации в вузе / В. Г. Иванов, И. Р. Искакова // Вестник Казанского технологического университета. - 2010. - № 12. - С. 173-179.

3. Ангеловский А. А. Профессионализация личности. Социальные агенты первичной и вторичной профессионализации / А. А. Ангеловский // Сибирский педагогический журнал. - 2011. - № 7. - С. 70-80.

4. Романова Е. С. 99 популярных профессий. Психологический анализ и профессиограммы / Е. С. Романова. 2-е изд. - СПб. : Питер, 2003. - 464 с.

5. Жиляєва Ю. М. До питання змісту курсу іноземної мови професійного вжитку для студентів спеціальності 'Політологія' / Ю. М. Жиляєва // Мова і світ : сучасні тенденції викладання іноземних мов у вищій школі : збірник матеріалів IV Всеукраїнського науково-практичного вебінару (29 листопада 2017 р.). - Житомир : Житомирський державний університет імені Івана Франка, 2017. - 123 с.

6. Програма з англійської мови для професійного спілкування - National ESP Curriculum / [Колектив авторів : Г. Є. Бакаєва, . А. Борисенко, I. І. Зуєнок, В. О. Іваніщева, Л. Й. Клименко, Т. І. Козимирська, С. І. Кострицька, Т. І. Скрипник, Н. Ю. Тодорова, А. О. Ходцева]. - К. : Ленвіт, 2005. - 119 с.

\section{REFERENCES (TRANSLATED \& TRANSLITERATED)}

1. Druzhilov S. A. Osvoieniie studentami modeli professii i professional'noi deiatel'nosti kak neobkhodimoie usloviie professinalizatsii [Assimilating the Model Profession and Prefessional Activity by Students as the Prerequisite for Professionalization] / S. A. Druzhilov // Obrazovatel'nyie tekhnologii i obshchestvo [Educational Technology and Society]. - 2010. - Vol. 13. - No. 4. - Pp. 299-318.

2. Ivanov V. G. Professional'noie stanovleniie studentov $\mathrm{i}$ protsess professionalizatsii $\mathrm{v}$ vuze [Professional Development of Students and the Process of Professionalization at the University] / V. G. Ivanov, I. R. Iskakova // Vestnik Kazanskogo Tehnologicheskogo universiteta [Bulletin of Kazan Technological University]. - 2010. No. 12. - Pp. 173-179. 
3. Angelovsky A. A. Professionalizatsiia lichnosti. Sotsial'nyie agenty pervichnoi i vtorichnoi professionalizatsii [Professionalization of a Person. Social Agents of Primary and Secondary Professionalization] / A. A. Angelovsky // Sibirskiy pedagogicheskiy zhurnal [Sibir Pedagogical Journal]. - 2011. - No. 7. - Pp. 70-80.

4. Romanova Ye. S. 99 Populiarnykh professii. Psihologicheskii analiz i professiogrammy [99 Popular Professions. Psychological Analysis and Job Profiles] / Ye. S. Romanova. $-2^{\text {nd }}$ ed. - SPb. : Piter, 2003. -464 p.

5. Zhyliaieva Yu. M. Do pytannia zmistu kursu inozemnoi movy profesiinoho vzhytku dlia studentiv spetsialnosti 'Politilohiya' [Revisiting the Issue of Designing the Content of an ESP Course for Students Specializing in Political Sciences] / Yu. M. Zhyliaieva // Mova i svit : suchasni tendentsii vykladannia inozemnykh mov u vyshchii shkoli : zbirnyk materialiv IV Vseukrainskoho naukovo-praktychnoho vebinaru (29 lystopada 2017 roku) [Language and the World : Modern Tendencies of Teaching Foreign Languages at Higher Education Institutions: Digest of the $4^{\text {th }}$ Ukrainian Applied Science Webinar of November 29, 2017. - Zhytomyr, Zhytomyr Ivan Franko State University, 2017. $-123 \mathrm{p}$.

6. Prohrama $\mathrm{z}$ angliis'koi movy dlia profesiinoho spilkuvannia - National ESP Curriculum [The Program of English for Professional Purposes - National ESP Curriculum]/ [G. Ye. Bakaieva, O. A. Borysenko, I. I. Zuienok, V. O. Ivanishcheva, L. Y. Kmymenko, T. I. Kozymyrska, S. I. Kostrytska, T. I. Skrypnyk, N. Yu. Todorova, A. O. Khodtseva]. - K. : Lenvit, 2005. - 119 p.

\section{Жиляева Ю. Н. Роль и место курса английского языка в процессе профессионализации студентов-} политологов.

В статье исследуются организачионные и методические основы обеспечения профессионализации студентов в высшем учебном заведении посредством усиления сотрудничества между преподавателями специализированных дисциилин и курса иностранного языка. Предложены средства и формы работь в рамках иноязычной подготовки студентов с иелью создания модели профессиональной

среды, профессиональной деятельности и Я-концепции будущчих политологов, которые составляют психологическую модель профессии. Установлен алгоритм разработки учебного модуля по иностранному языку, ориентированного на профессионализацию студентов.

Ключевые слова: профессионализация студентов, первичная профессионализация политологов, междисциплинарные связи, учебный модуль по иностранному языку, иностранный язык для профессиональных иелей.

\section{Zhylyayeva Yu. M. The Role and Place of the English Course in Professional Development of Political Scientists at the University Level.}

The article studies the principles and the framework of ensuring the professional development of students

specializing in the political sciences at the university level, with focus on enhancing the links between specialized courses and the ESP course. The methodology behind the research lies in creating the psychological model of the profession of a political scientist, analyzing its structural components, in particular, the model of the professional environment, professional activity and the professional self-concept, and studying the ways the course of English may contribute to the professional development of students.

The following functions of the ESP course were singled out and detailed in view of the specialization: information, organization and control. These functions were further studied to provide a set of ways, forms, methods and specific tasks designed to engage students in the English-speaking professional discourse, both inside and outside the classroom.

The model of professional activity was constructed based on the professional profile of a political scientist, and a set of communicative functions were specified for the respective professional context, which laid the foundation for developing the algorithm of planning a learning module of an ESP course and a set of objectives of the ESP curriculum for students of political sciences.

Having specified the objectives and the content of professional development by means of an ESP course, the article further suggests organizational and methodological framework for implementing interdisciplinary links

between specialized disciplines and ESP. However, early professional development of students during the General English course still needs to be studied.

Key words: ESP for political scientists, professional development of students, primary professionalization, interdisciplinary links. 